\title{
高温高速加硫技術
}

西沢仁

\section{High Temperature and Efficient Vulcanization Technology}

Hitoshi NISHIZAWA (Nishizawa Institute of Technology 245-7 Kamiiidacho, Izumiku, Yokohama, 245-0018, Japan)

In rubber industry the productivity improvements are the most important key technology and must be studied more eagerly concerning these material compounding and processing technology. High temperature and efficient vulcanization technologies have been applied in continuous vulcanization process and injection molding process. I introduce the continuous vulcanization technology, mainly Catenary Continuous Vulcanization(CCV), Vertical Continuous Vulcanization(VCV), Liquid Curing Medium Vulcanization(LCM) and curing systems especially about the characteristics and advantages of these technologies to improve the productivity.

Key Words : CCV, VCV, LCM, EV Cure

\section{1. は じ め に}

ゴム工業における生産性向上技術は, 多品種少量生産が 多く比較的付加価值の高いゴム製品においては低コスト高 性能を目指す上で最も重要なキーテクノロジーである.

ゴム製品の加硫としては，プレス成形加硫，射出成形加 硫が最も多く使用されているが，生産性の高いと言われる 連続加硫は電線, ケーブル, ホース, 長尺異形品, シート 等に使用されている特徴的な加硫技術である. 最近は, 押 出後に連続的に加硫管に入って加硫される連続加硫方式 と, 射出成形に加え, プレス成形においても高温加硫が適 用されている。ここで言う高温加硫の一般的な定義はない が $170{ }^{\circ} \mathrm{C}$ 以上,又は $200{ }^{\circ} \mathrm{C}$ 以上を指すことが多い.

高温加硫は, 生産効率が上がるが高温であるがために加 工中のスコーチ管理, 加硫戻り, 架橋鎖の切断による物性 の低下, 厚肉製品の内部, 外部での加硫のアンバランス, 表面層の加硫戻り等の課題がある. 今回は, 高温高速加硫 方式の問題点と対策について考察したい.

\section{2. 高温高速加硫技術}

\section{1 連続加硫技術}

連続加硫方式の基本方式は, 押出されたゴムを高温水蒸 気, 高温空気或いは高温無機塩が満たされた加硫管, 加硫 槽の中に連続的に導入し, 一般には $200{ }^{\circ} \mathrm{C}$ 以上の温度で加 硫, 冷却し, 製品として引取る加硫方式 (Catenary Continuous Vulcanization (CCV), Vertical Continuous Vul- canization (VCV), Liquid Curing Medium Vulcanization (LCM), Pressure Liquid Curing Medium Vulcanization (PLCM), Fluid Bed Vulcanization (FB)等)である. シリ コーンゴムの場合は架橋剤の適正な選択により常圧加熱空 気浴中 (Hot Air Vulcanization (HAV)) での加硫, 高周波 加硫 (Ultra High Frequency Vulcanization (UHF)) と HAV との併用方式も使用されている.

その後電線, ケーブルでは架橋ポリエチレン絶縁ケーブ ルの連続架橋方式が進歩してきて高温不活性ガス $(5 \sim 6$ 気圧) 中での架橋, 高圧加圧ヘッド方式, 誘導加熱補助方 式等により乾式架橋, 多層同時押出技術が進歩してきてい る. 代表的なゴムの連続加硫方式としてカテナリー連続加 硫装置 $(\mathrm{CCV})$, 垂直連続加硫装置 $(\mathrm{VCV})$, 液体加硫装置 (LCM), 加圧液体加硫装置 (PLCM), その他を表 $1^{1)}$, 図 1 ～図 $4^{2,3)}$ に示す.

連続加硫における進歩として特に架橋ポリエチレンで問 題となる加硫管内での加硫初期での溶融, 軟化による变形, 偏肉対策が上げられる。これは加硫管入り口付近での温度 制御機構である. 最も代表的な例としてNEXTROM社で

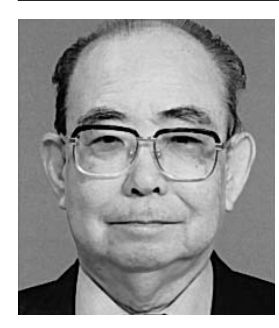

西沢 仁; 西沢技術研究所 ( $7245-0018$ 横浜 市泉区上飯田町 245-7).1956 年新潟大学工学 部応用化学科卒業. 同年, 昭和電線電纜株入 社, 1998年同社退社. 現在に至る. 専門は, ゴム・エラストマー物性, 成形加工性, 防振, 制振, 免震技術, 材料設計, 高分子難燃化技 術. 日本ゴム協会技術委員会幹事, マテリア ルライフ学会理事等, 難燃材料研究会会長. 
行われている例を図 $5^{4,5)}$ に示すが，EHT方式と呼ばれ る冷却循環方式を取り入れ導体に被覆される絶縁体の溶融 状態を制御して重力による変形を防止している (図 6$)^{4,5)}$. ゴムの CCV， VCVでは熱媒体として水蒸気が未だ使用さ れているが，架橋ポリエチレンの場合は，水トリー(電圧 と水分共存の状態で木の枝状に進展する破壊現象を言う） の防止と電気特性の向上を考虑して，350 ${ }^{\circ} \mathrm{C}$ 前後の不活性 ガス (窒素ガス)を使用して $5 \mathrm{~kg} / \mathrm{cm}^{2}$ 程度の加圧下で架橋 が行われる。

更に架橋ポリエチレンの場合，架橋促進のためにヘッド 部での誘導加熱による温度上昇，高圧加圧ヘッドによる温 度上昇方式も開発されている。ゴム材料の場合はシェアー ヘッド押出方式を利用した高速せん断回転によるヘッド部 での迅速温度上昇方式が採用される場合もある(図 7$)^{6)}$.

その他連続加硫の進歩に貢献しているのが押出設備, 技 術の進歩である。 CCV，VCVにおいてはまずスクリュー 構造の進歩がある。スクリュー構造は，図８に示すように 大きく分けてフルフライト，バリヤー，ミキシングの 3 種 類に分類される．連続加硫において望まれる性能は迅速な 可塑化と小さな温度変動である。これにはバリヤー，ミキ シング構造が適している.ゴムでも架橋ポリエチレンでも
表 1 連続加硫の種類と特徵

\begin{tabular}{|c|c|c|}
\hline 種類 & 基本方式 & 特徵 \\
\hline $\begin{array}{l}\text { CCV } \\
\text { (カテナリー型) } \\
\text { VCV (垂直型) }\end{array}$ & $\begin{array}{l}\text { ゴム, 架橋ポリエチレン } \\
\text { を押出機で押出すと同時 } \\
\text { に加硫管に導入し高温で } \\
\text { 連続的に加硫(架橋)する }\end{array}$ & $\begin{array}{l}\text { 熱媒体(ゴムは蒸気, 加熱 } \\
\text { 空気. 架橋ポリエチンン } \\
\text { 加熱窒素ガス) 加圧 (蒸気 } \\
\text { は } 15 \mathrm{~kg} / \mathrm{cm}^{2}, \text { 窒素ガス } \\
\left.\text { は約 } 5 \mathrm{~kg} / \mathrm{cm}^{2}\right) \\
\end{array}$ \\
\hline $\begin{array}{l}\text { LCM, } \\
\text { (溶融塩加硫) } \\
\text { PLCM } \\
\text { (加圧タイプ） }\end{array}$ & $\begin{array}{l}\text { 真空押出後, 高温の無機 } \\
\text { 溶融塩中に通しがら加 } \\
\text { 硫冷却する } \\
\text { 発泡し易いため圧力タイ } \\
\text { プも有り }\end{array}$ & $\begin{array}{l}\text { 乾式で熱伝達良 } \\
\text { 発泡し易い } \\
\text { 無機塩は危険物 } 1 \text { 類 }\end{array}$ \\
\hline $\begin{array}{l}\mathrm{UHF} \\
\text { (高周波加硫) }\end{array}$ & $\begin{array}{l}\mathrm{UHF}(2580 \mathrm{MHz}) \text { による } \\
\text { 誘電損失を利用した発熱 } \\
\text { により加硫. 通常 HAV } \\
\text { と併用する }\end{array}$ & $\begin{array}{l}\text { ベント脱泡が必要 } \\
\text { 誘電損失の大きな配合 }\end{array}$ \\
\hline $\begin{array}{l}\mathrm{FB} \\
\text { (流動床加硫) } \\
\mathrm{PFB} \\
\text { (加圧タイプ) }\end{array}$ & $\begin{array}{l}\text { 加熱ガラスビーズにより } \\
\text { 空気, 窒素ガスを吹付け } \\
\text { て加硫. 真空押出しが必 } \\
\text { 須であるが加圧タイプも } \\
\text { 有り }\end{array}$ & $\begin{array}{l}\text { ガラスビーズの深さで圧力 } \\
\text { 調整 } \\
\text { 熱率は比較的高い }\end{array}$ \\
\hline ロート加硫 & $\begin{array}{l}\text { 回転加熱ドラムでのエン } \\
\text { ドレスベルトによるゴム } \\
\text { の圧着により加硫 }\end{array}$ & $\begin{array}{l}\text { バンド圧力, } 5 \text { ～} 20 \mathrm{~kg} / \\
\mathrm{cm}^{2} \\
\text { 加圧面と背面の温度差大 } \\
\text { 加圧面の摩によるずれ } \\
\text { バンド継ぎ目の厚さ不均一 }\end{array}$ \\
\hline $\begin{array}{l}\text { 放射線架橋 } \\
\text { (電子線架橋) }\end{array}$ & $\begin{array}{l}\text { 電子線によるジート, チ } \\
\text { ユーブ, 細物電線, タイ } \\
\text { ヤ用ゴムシートの照射 }\end{array}$ & $\begin{array}{l}\text { 電子線透過厚さの限界 } \\
(500 \mathrm{keV} \text { で約 } 1 \mathrm{~mm})\end{array}$ \\
\hline $\mathrm{HAV}$ & $\begin{array}{l}\text { 空気浴加硫 } \\
\text { (シリコーンゴム) }\end{array}$ & $\begin{array}{l}\text { 発泡し易い (架橋剂指定) } \\
\text { 低熱効率 }\end{array}$ \\
\hline
\end{tabular}

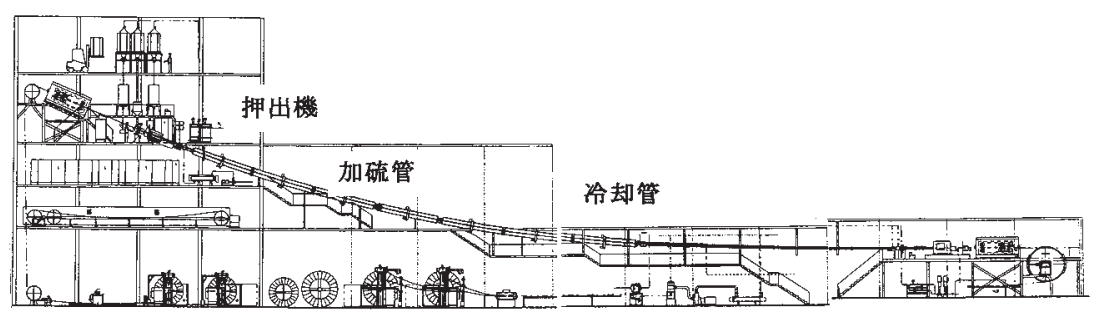

引取装置

図 1 Troester社のCCV 装置

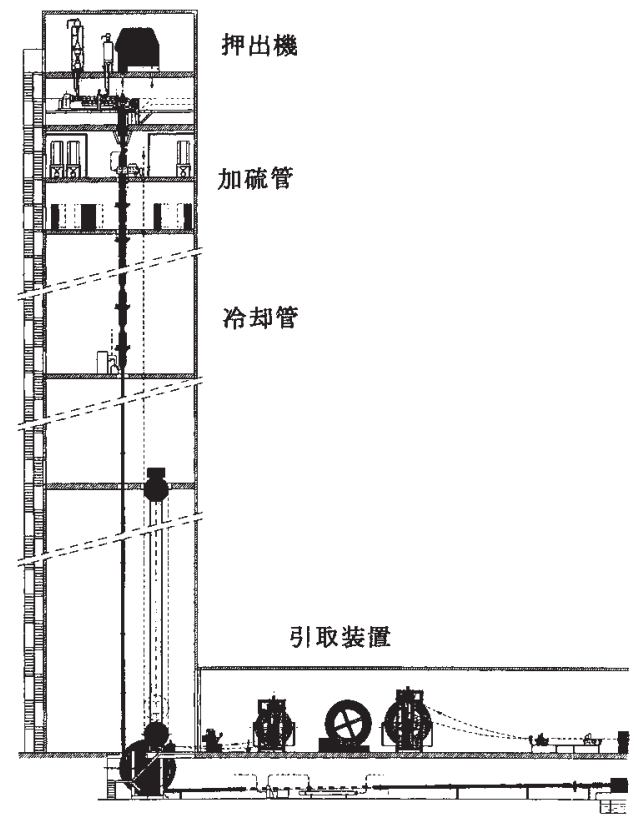

図 2 Troester社の VCV 装置

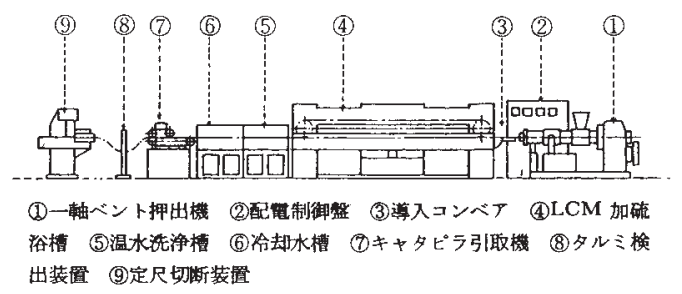

LCM 加硫ライン

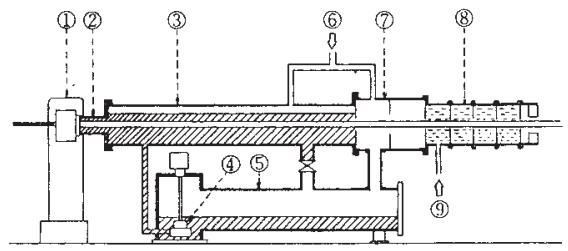

(1)外層ゴム押出㯨 (2)スプライスボックス (3) 加 压加硫管 (LCM) (4)容融塩供給ポンプ (5)溶融 程眝槽 (6)加圧気体供給 (7)中間分離室 (8)加圧 水治部 (9)椧却水入口

PLCM 加硫ライン

図 3 LCM 加硫方式 (一般, 加圧式) 


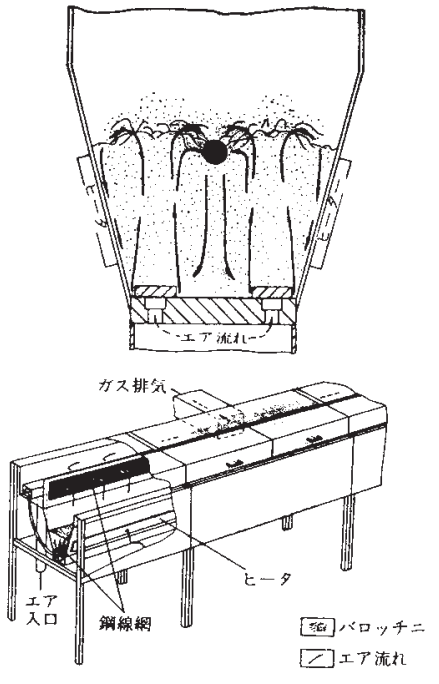

FB 加硫方式

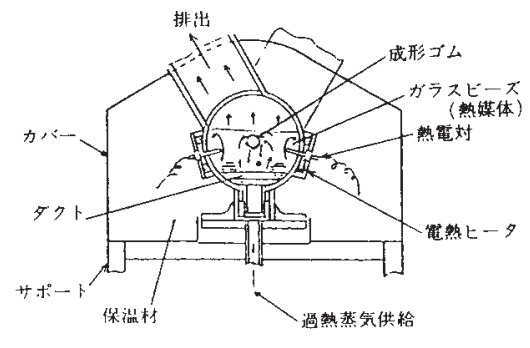

加圧 FB 加硫方式

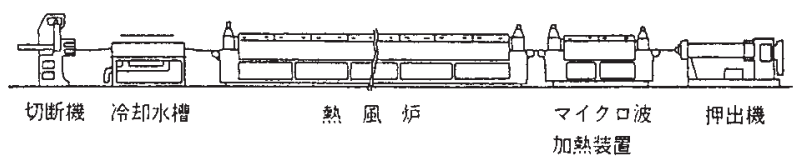

HAV-UHF 加硫方式

図 4 その他連続加硫方式

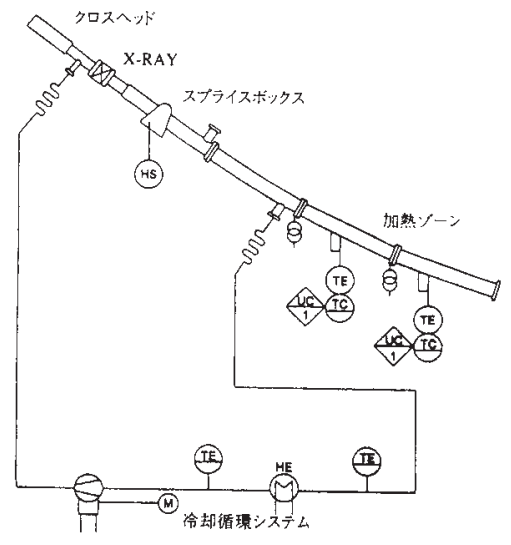

図 5 CCVラインでのクロスヘッド後におけるEHT方 式による冷却温調システム (NEXTROM社技術 資料)

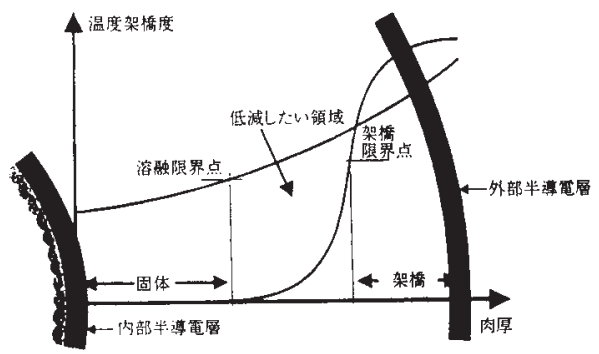

図 6 EHT方式によるケーブル絶縁体内の温度分布と 溶融，架橋状態 (NEXTROM 社技術資料)
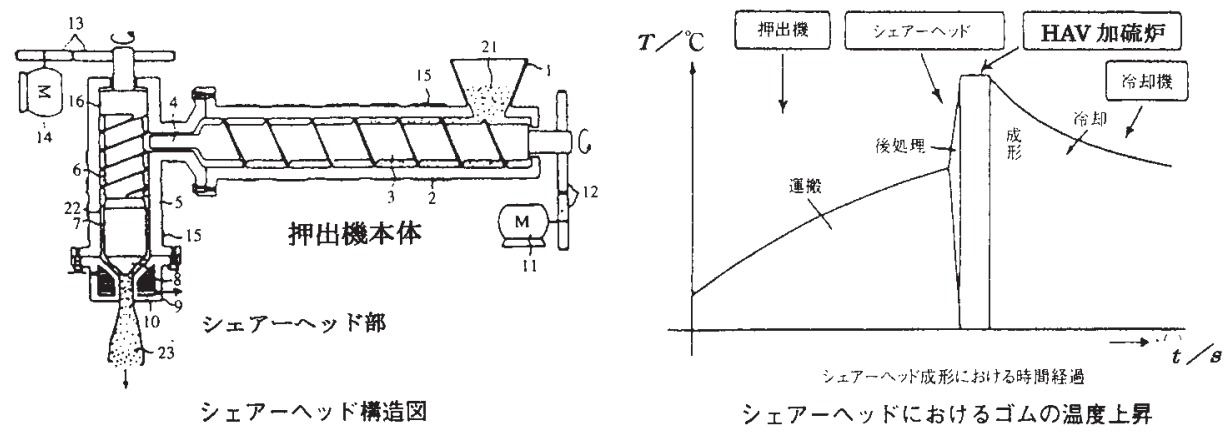

図 7 シェアーヘッド構造とゴムの温度上昇(三葉製作所技術資料)

同じであり広範囲の粘性流動特性の材料の押出に適用でき る. 絞り比, $L / D$, 圧縮比 $(C R)$, 供給部, 圧縮部, 軽量 部各部の構成比, 溝深さ等スクリューの基本構造の検討と 共にこの 3 種類のスクリュー構造の選択が重要である．混 練り効果を上げることがスクリュー内のゴム材料の温度の ばらつきを小さくすることが出来ることを再認識しておく ことが重要である。

LCM，FB，HAV-UHFにおける押出しでは真空押出し による巻达みエアー，揮発分の除去に真空押出用スクリュ 一が活躍している．特にスクリュー長さ方向の圧力分布が 真空引き箇所でゼロに戻るため 2 段階の圧力分布を示すの で，ブレーカープレート，ヘッド部における圧力制御が難
しくなる。

連続加硫における温調ダイ，スクリュー温調も重要な技 術である，スクリュー温調は，通常の押出作業では行われ ないが，連続加硫のように高温押出しではヤケの安定性， 押出量の安定性に効果が高い.ダイの温調はダイとニップ ル間のコンパウンドスペースでのゴムの流れを安定化して ヤケ，目やに(ダイ先端に蓄積する析出物)の原因を低減す る効果が有り，外観の向上にも貢献する。適正アングル $\left(2 \alpha=75{ }^{\circ} \mathrm{C}\right)$ の範囲も拡大される. 温調ダイの製作，取 付けには工夫が必要になる。連続加硫における押出量の安 定性は重要であり，フィードの安定性とブレーカープレー トでの金網の詰まりによる変動には充分な注意が必要であ 

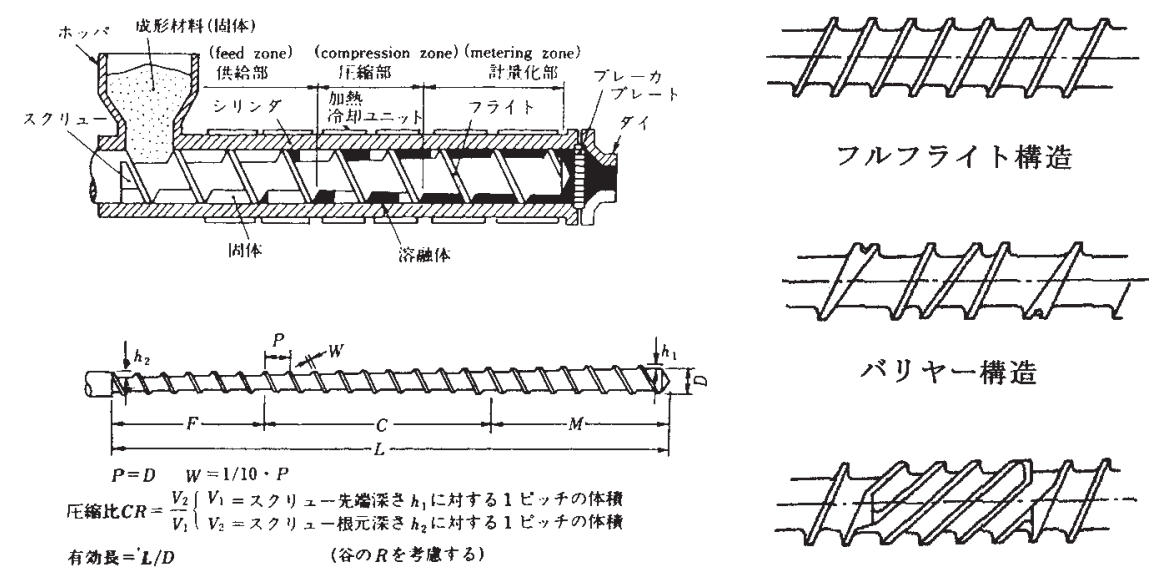

ミキシング構造

図 8 押出機用スクリュー基本構造と連続加硫用スクリュー－バリヤー，ミキシング構造

り, 加硫管内での外径測定とフィードバック制御が要求さ れる. 高温, 高速連続加硫での加硫管から冷却管へのシー ル部での押出速度 (線速)の変動を防止する機構に種々の工 夫がなされている，その一例を図 9 に示す.

LCMによる連続加硫は，亜硝酸塩を主体とする無機塩 を加熱溶融して押出ゴムをその中に浸せきして加硫するた め圧力は低く発泡し易い。最大の問題はいかにしてベント 押出による効果的な脱泡を行うかである．揮発分，水分の 少ない配合と混練り，脱水剂としての酸化カルシウムの配 合，効果的な真空引き，押出時の巻き込みエアーの低減の ためのフィードの安定化によるスクリュー内での材料枯渇 現象の回避，スクリュー構造，ブレーカープレートとメッ シュの適正選択による揮発分の除去が重要な技術となる. 現場での管理として熱媒体の無機塩付着繊維，紙等の消防 法に準拠した火災対策，冷却水の排水処理が要求される.

HAV-UHFラインについては，HAVはLCMに類似し た注意が必要になるがUHFについては発熱性を考慮した 配合設計と配合剂の分散，ホットスポットの回避，照射時 間管理がポイントになる。

ベント押出しが必須な LCM，FB，HAV，UHFにおい て共通して問題となるのは，真空引時に逃出する加硫剤， 老化防止剂, 加工助剂等である。逃出する量はそれほど多 くはないが時には加硫の遅れに繋がる場合がある．分解温 度の高い揮発性の低い有機配合剂の選択，予め揮発量を検 証して相当量だけ過剩に配合する等の対策が取られる。

高温高速加硫における肉厚製品の加硫度の不均一性対策 には，肉厚と熱伝導度を考慮した適正な線速の設定が重要 である．線速が加硫戻り現象とバランスが取れないと，表 面層の加硫戻りが起こり製品表面の粘着，物性低下に繋が り易い。また，後述する耐熱性加硫系，加硫の速いポリマ 一構造, 配合剤の選択も必要になる。

ゴム材料の連続加硫における熱媒体としては CCV, $\mathrm{VCV}$ の場合は未だ水蒸気が使われるが，架橋ポリエチレ
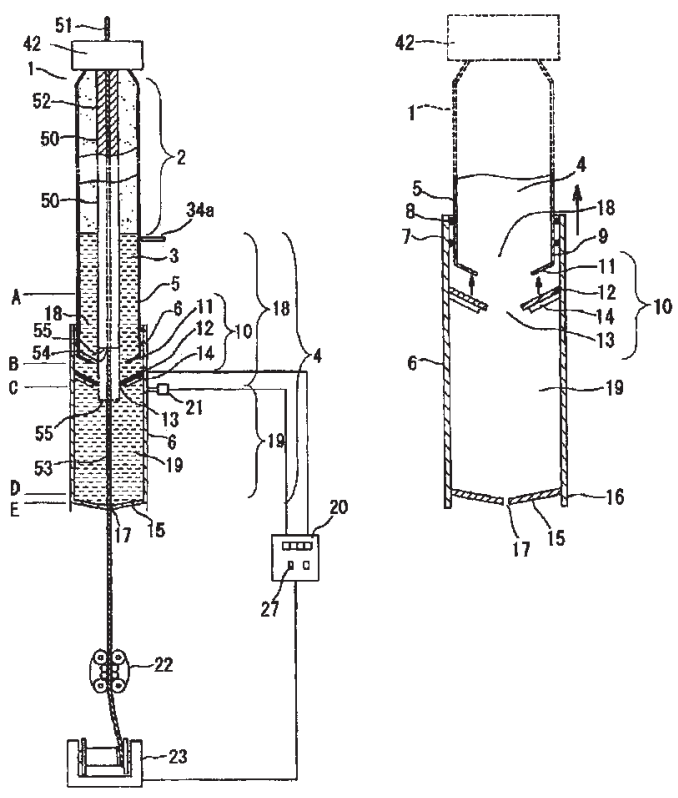

図 9 連続加硫 $(\mathrm{VCV})$ における線速変動防止装置(特開2002-109979) 上図は，上部(1)の架橋管から入ったケーブル (50)を，下部に設置す る牽引機 (22)によってケーブル先端部 (5) が孔開度可変パッキング (12)に達する時に引張力と逆方向の反力を相互に調整して，パッキ ング室 (19)で起こる圧力降下による線速の変動を防止する装置 その他主要部は, 次の通り

(2) 加圧加熱部, (3) 冷却水, (4) 加圧冷却部, (10) 孔開度調整パッキ ング装置，(15)端末パッキング，（15)端末パッキング等

ンでは不活性ガスの窒素ガスが使われる。水蒸気の場合は 通常 $15 \mathrm{~kg} / \mathrm{cm}^{2}$ 前後の圧力 (約 $205{ }^{\circ} \mathrm{C}$ ) で行われるが不活 性ガスではかなり低い $5 \mathrm{~kg} / \mathrm{cm}^{2}$ 程度の圧力が一般的で ある. 水蒸気の場合には水分の影響を受ける場合があり， 充てん剂の表面処理, 加水分解性の配合剂の回避, 揮発性 加工助剤の回避等の配慮がなされる。厳しい電気特性を要 求される場合は水蒸気の浸透による電気特性の低下を防ぐ 必要があり, 場合によっては加硫後乾燥を行うこともある.

\section{2 金型成形加硫技術}

最近はプレス成形加硫，射出成形加硫においても高温高 
速加硫条件が採用される，加硫方式としては電熱，誘導加 熱, 高周波加熱, せん断発熱を利用している. その代表例 を図 $10^{7)}$, 図 $11^{8)}$ に示す。

高温射出成形加硫の場合は特に射出部の先端のノズルか ら射出される前の計量部における滞留, 温度制御によるス コーチの防止が重要になり，材料の逆流防止機構を設けた 先入れ先出し構造, ノズル先端の滞留防止構造, 優れた温
調制御等の工夫がなされている(図 12 ).

金型から見た高温加硫における課題としては，スコーチ 防止のための金型構造として温調金型，ランナーレス金型 が挙げられる．温調金型は，スプルーからランナーを通っ てゲートまでのゴムを冷却してスコーチを防止する。断熱 板を設けて加熱板からの熱を遮断しながらゴムの温度上昇 を抑える。冷却媒体の冷却路の設置位置, 長さ, 内径等が

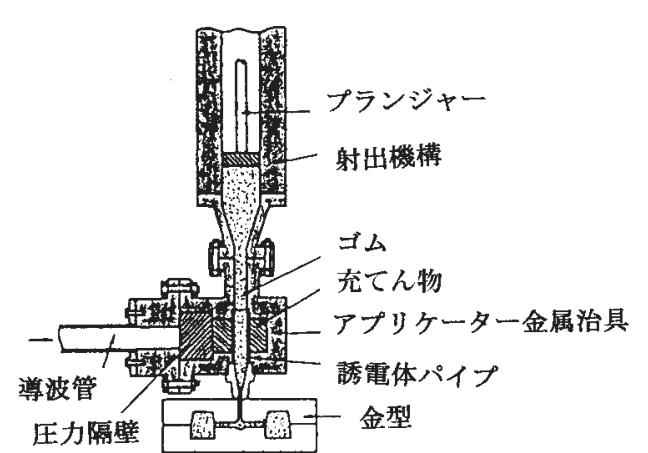

高周波加熱方式

上部から下部へ射出されるゴムが誘電体 パイプ内を通過する時に高周波を付加され 急速な加热が起こる

（松田製作所技術資料）

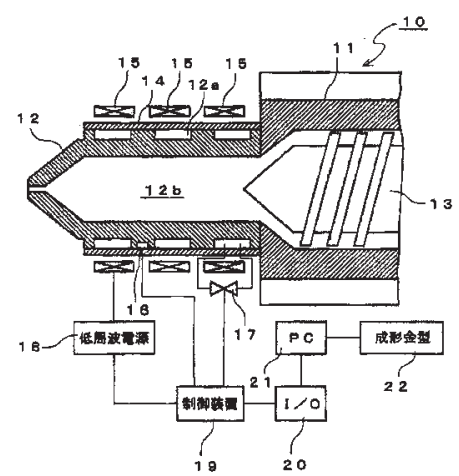

誘導加熱方式

上図に示寸射出成形ノズル部の先端 に設置された誘導加熱コイル（15）に ノズル部(12)を通過するゴムが急速に 加熱される

（特開 2005-334483）

図 10 射出成形機における高温高速加硫方式

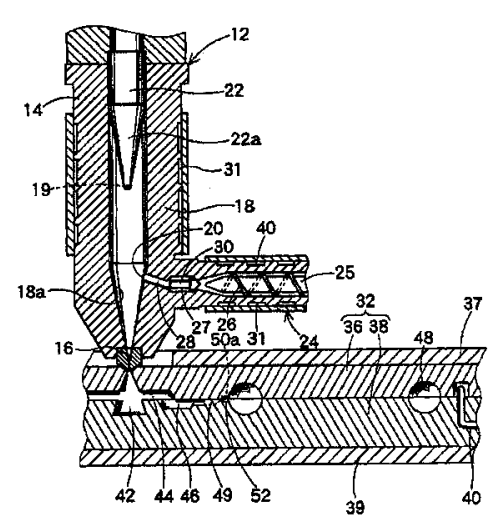

（12）射出成形機、（16）射出ノズル

（18）射出ポット、(32) 射出金型

（36）上型、(38）下型、(42) スプルー

(44) ランナー、(46) ダート

(48) 製品キャビテイ(49) 平板状淟

（50）分吱流入路、(50a) オリフィス

リング状ゴム製品射出成形法

射出成形機の射出ポット（14）内のコムを 溶骶しノズル(16)加金型（32）へ射出する 祭、ダート(46)の材料流れを下型(38)側に形 成した平板状溝(49)で、キャビテイ(48)の雨 端に分流させる。ダートの製品キャビテイと 接続される所定のオリフィス(50a)でせ九断発 熱を与えながら製品キャビテイに注入する。 （特開 2005-279949）

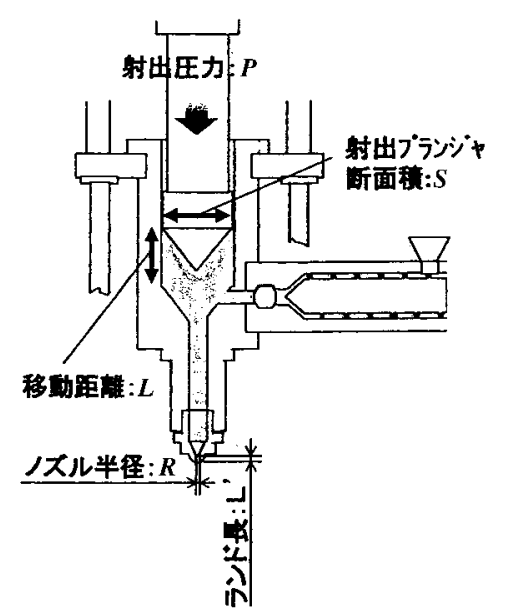

せん断速度と発熱の関係

$\Delta T=2 \cdot L \cdot \eta \cdot \gamma / J \cdot \rho \cdot C \cdot R$

$\eta$ - 材料粘度, $C$ - 比熱

$\gamma$ 一 せん断速度

高せん断発熱を利用した射出成形 射出成形機のプランジャー部において 高圧, 高せん断速度を付加してせん断 発熱を与え, 高速加硫を行う。

(木村洋治; 日本ゴム協会成形加工分

科会講演資料 (2006))

図 11 射出成形機における高せん断速度，高射出圧による温度上昇を利用した高温高速加硫方式 


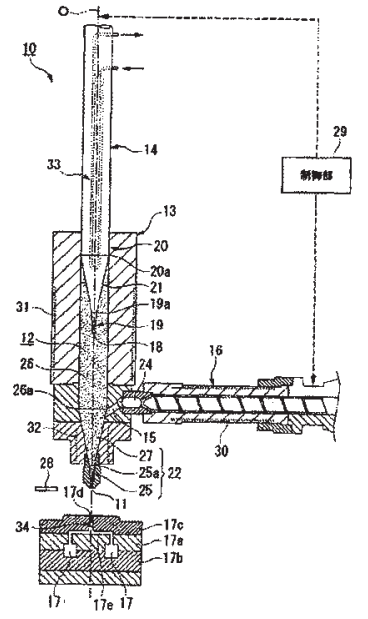

（10）射出成形機、（11）ノズル孔

（12）計量空間、(13）シリンダー

（14）プランジャー、(15） 供給機

（16）押出機、(17）金型キャビテイ

（18）先端、（19）テーパー部

射出計量部の内部空間の䊎合精度をあげて

射出後ゴムの滞留、残存をなくしてヤケの

発生をなくした構造

計量部滞留防止を考慮した射出成形機

（特開 2008-87374）

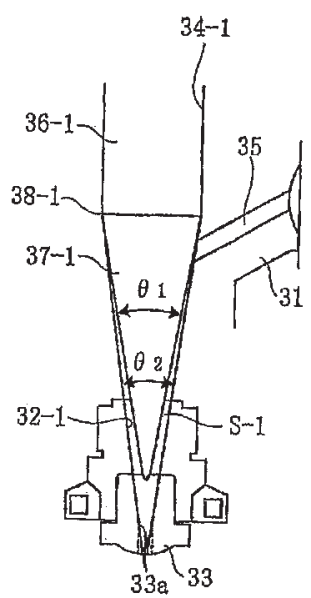

（31）金属ケース、(33）射出ノズル

（34）射出ポット、（35）側部投入口

(36) プランジャー、（37）先端部

(S) 隙間

計量部内部構造を滞留、残留ゴム を少なくした射出成形機

滥留防止計量部を有寸る射出成形機

（特開 2004-048069）

図 12 射出成形機高温加硫における計量部の滞留, ヤケ防止構造

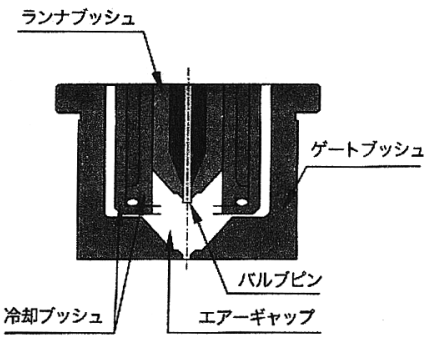

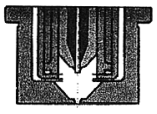

原点

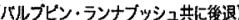
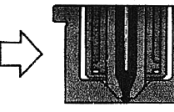

射出

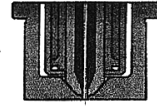

ゲートシール (パルブピン前進)

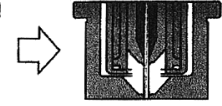

加硫 (ランナプッシュ後退)
図 13 完全ランナーレス金型構造(世紀秼技術資料)

工夫される．ランナーレス金型は射出成形機のノズル，ス プルーからランナーを設けないで直接ゲートに直結する構 造でゴムのヤケがないので高温加硫には適している，金型 メーカーが発表している一例を図 $13^{9)}$ に示すが，ゴムが ゲートから注入されるとランナーブッシュが後退して高温 の金型から遮断され，ゴムのヤケを防ぐ工夫がなされてい る.

\section{3. 高温高速加硫用ゴム材料の配合設計}

\section{1 配合設計のコンセプト}

高温高速加硫用ゴムは，加硫温度が高いために基本的に
加硫速度が速いことと, 耐熱性が優れていることが要求さ れる. 特にポリマーの選択, 加硫系の選択が重要である. ポリマーの選択は各種ゴム材料について評価されている耐 熱許容温度（表 2 )を参考に選択する必要があるが，次に述 べる加硫系 (架橋系)の選択及び金属酸化物，耐熱性老化防 止剤, 耐熱性加工助剤の選択が重要な要因となる.

\section{2 加硫系の設定}

高温高速加硫系の加硫特性としては，図 14 に示すよう な加硫曲線のスコーチタイムが長く適正加硫時間が短く, 平坦効果に優れたものが適していることはよく知られてい る.この三つのバランスが取れていることが重要である. まずスコーチタイムであるが，CCVの例を取って我々

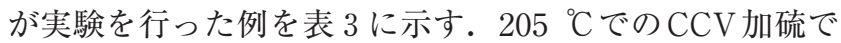
約 10 時間以上連続作業可能であるスコーチタイムは，へ

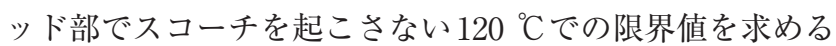
と 12〜14分になる. 加硫中のヘッドのダイス先端温度を 測定すると 190 〜 $195{ }^{\circ} \mathrm{C}$ 迄上昇しているがゴムが常に流動 しているためにヤケが起こらないものと考えられる.

高温高速加硫には硫黄一促進剂系と過酸化物＋共架橋剤 系が使われている. 加硫系の課題は, スコーチ安定性, 加 硫速度, 架橋度の低下 (加硫戻り等), 厚さ方向の加硫度の 均一性である. 硫黄一促進剤加硫系は通常加硫系, セミ $\mathrm{EV}$ 加硫系, $\mathrm{EV}$ 加硫系が使われ (表 4), 耐熱性老化防止 剤と混練加工時の安定剤を併用した耐熱性配合が適してい 
表 2 各種ゴム材料の耐熱許容温度

\begin{tabular}{|c|c|c|}
\hline $\begin{array}{l}\text { 耐熱許容 } \\
\text { 温度 } /{ }^{\circ} \mathrm{C}\end{array}$ & ゴム材料の種類 & グレード別耐熱性 \\
\hline 60 & NR & \\
\hline 70 & SBR, IR, BR & \\
\hline 80 & $\begin{array}{l}\text { NBR, CR, IIR, } \\
\text { NBR } / \text { PVC }\end{array}$ & $\begin{array}{l}\text { NBRはBR量多いほど低下 } \\
\text { IIRは低不飽和度ほど耐熱性向上 } \\
\text { DVD 導入過酸化物架橋 IIRは耐熱 } \\
\text { 性良好 } \\
\text { CRは非硫黄変性タイプ>硫黄変性 } \\
\text { タイプ }\end{array}$ \\
\hline 90 & $\operatorname{EPDM}($ 硫黄加硫) & $\begin{array}{l}\mathrm{ENB}>1,4 \mathrm{HD}>\mathrm{DCPD} \text { (酸素吸収) } \\
\mathrm{ENB}>\mathrm{DCPD}>1,4 \mathrm{HD} \text { (機械強度) } \\
\mathrm{DCPD}>\mathrm{ENB}>1,4 \mathrm{HD} \text { (応力緩和) } \\
\text { 二重結合含有量の増加によりり低下 } \\
\mathrm{E} / \mathrm{P} \text { 比が高いと耐熱性向上 } \\
\text { 触媒残渣量の増加で耐熱加水分解性 } \\
\text { 低下 }\end{array}$ \\
\hline 100 & $\begin{array}{l}\text { EPDM } \\
\text { (過酸化物架橋) }\end{array}$ & 過酸化物架橋＞硫黄加硫 \\
\hline $105 \sim 110$ & $\begin{array}{l}\text { CSM, 塩素化 } \\
\text { PE,EO } \\
\text { ハロゲン化IIR }\end{array}$ & 塩素化 PE, 過酸化物架橋 > 硫黄加硫 \\
\hline $120 \sim 130$ & $\begin{array}{l}\text { 超耐熱 EPDM, } \\
\text { 水添 NBR } \\
\text { ACM }\end{array}$ & $\begin{array}{l}\text { 超耐熱EPDMは過酸化物架橋+耐熱 } \\
\text { 老防 }\end{array}$ \\
\hline 150 & $\mathrm{Q}$ (湿熱) & $\begin{array}{l}\text { Q は湿熱, 乾熱で耐熱性が大幅に変 } \\
\text { わる }\end{array}$ \\
\hline 180 & $\mathrm{Q}$ (乾熱) & \\
\hline $200 \sim 220$ & $\begin{array}{l}\text { フルオロシリコーン } \\
\text { フッ素ゴム }\end{array}$ & \\
\hline
\end{tabular}

注 1 ) 約 20 年間連続使用可能最高温度で評価(アレニウス寿命推定実験 により推定）

2 ）ゴム耐熱性ランク $\mathrm{FKM}>\mathrm{VMQ}>\mathrm{ACM}>\mathrm{AEM}>\mathrm{EPDM}>\mathrm{CO} /$ $\mathrm{ECO}=\mathrm{CM}>\mathrm{CSM}$

$>\mathrm{CR}>\mathrm{IIR}>=\mathrm{NBR} / \mathrm{PVC}>\mathrm{SBR}>\mathrm{NR}$

3 ）高温高速加硫では耐熱性に優れたグレードの選択が重要

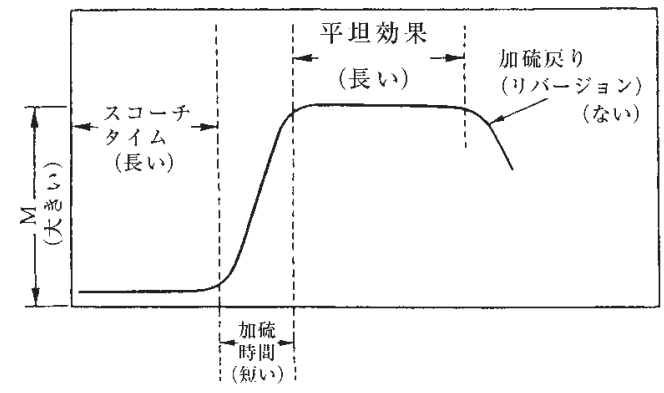

図 14 高温高速加硫に望まれる加硫曲線

る.

硫黄一促進剂加硫で加硫温度が上昇したり，加硫時間が 長くなったりするとモノスルフィド結合が増加するが架橋 密度は低下する。これは分子内架橋, ペンダントが増えて いるためである。これが熱老化性に影響して強度を低下し ていく。これらを改良するための耐熱性架橋剂として1,6ビス $(N, N$ '-ジベンジルチオカルバモイルジチオ)へキサン， HTSが出てきている (図 15) ${ }^{10-12)}$ 。これらは，架橋形態が S-S 結合よりもC-C 結合の方が耐熱解離エネルギーが高く 安定していることを利用して架橋点をC-C 結合としたもの
表 3 高温高速加硫系の加硫，スコーチ特性(例)

\begin{tabular}{|c|c|c|}
\hline 特性值 & $\mathrm{CCV}$ 加硫 & 射出成形加硫 \\
\hline $\begin{array}{l}\text { 適正加硫条件 } 1 \\
\text { (熱伝導度を考慮) }\end{array}$ & $205{ }^{\circ} \mathrm{C}$ 約 20 秒 & $200{ }^{\circ} \mathrm{C} \quad 2 \sim 3$ 分 \\
\hline $\begin{array}{c}\text { スコーチタイム }{ }^{2} \\
M L 120^{\circ} \mathrm{C} ， 5 \text { 点上昇 }\end{array}$ & $\begin{array}{c}12 \sim 14 \text { 分 } \\
\text { (連続 } 10 \text { 時間以上作業) }\end{array}$ & $6 \sim 7$ 分 \\
\hline 加硫戻り & 小さい & 小さい \\
\hline 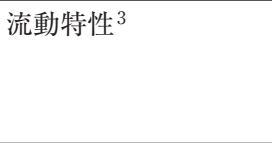 & $\begin{array}{l}\text { 高流動性(低粘性) } \\
\text { 低柋力緩和 (夕膨張) } \\
\text { 低圧力損失 }\end{array}$ & $\begin{array}{l}\text { 高流動性 (低粘性) } \\
\text { 適正緩和特性 (金型 } \\
\text { 内圧力上昇特性) } \\
\text { 低圧力損失 }\end{array}$ \\
\hline
\end{tabular}

1 適正加硫時間は製品肉厚, 形状によって異なる.

2 スコーチタイムは, 連続 10 時間以上ヘッド部でヤケを発生しない で押出可能な条件としている.

3 連続加硫押出作業時の流動特性は, 粘性が低く限りなく流動性の高 いゴム材料が望まれるが，加硫管内でのダレ落ち，変形に耐える緩 和特性は必要となる。

表 4 高温高速加硫に適した硫黄一促進剤系の特徵

\begin{tabular}{|c|c|c|c|}
\hline 加硫系, 特性 & 通常加硫系 & セミ EV 加硫系 & $\mathrm{EV}$ 加硫系 \\
\hline \multicolumn{4}{|l|}{ 加硫剤配合 } \\
\hline 硫黄 / phr & $2.0 \sim 3.0$ & $1.0 \sim 1.7$ & $0.4 \sim 0.8$ \\
\hline 促進剤 / phr & $1.2 \sim 1.4$ & $1.2 \sim 2.5$ & $2.0 \sim 5.0$ \\
\hline 硫黄 / 促進剤比 & $1.5 \sim 2.0$ & $0.7 \sim 1.5$ & $0.4 \sim 0.1$ \\
\hline \multicolumn{4}{|l|}{ 架橋形態 } \\
\hline$-\mathrm{Sx}-, \quad-\mathrm{S}_{2}-(\%)$ & 95 & 50 & 20 \\
\hline$-\mathrm{S}-(\%)$ & 5 & 50 & 80 \\
\hline 環状 - S - & 高 & 中間 & 低 \\
\hline \multicolumn{4}{|l|}{ 特性 } \\
\hline 低温結晶化抵抗 & 高 & 中間 & 低 \\
\hline 耐熱性 & 低 & 中間 & 高 \\
\hline 加硫戻り & 低 & 中間 & 高 \\
\hline 屈曲抵抗 & 高 & 中間 & 低 \\
\hline $\begin{array}{r}\text { 圧縮永久ひずみ } / \%, \\
\left(70{ }^{\circ} \mathrm{C}, 22 \mathrm{~h}\right)\end{array}$ & 20 & 15 & 10 \\
\hline
\end{tabular}

注） 1 ）加硫条件と架橋形態

加硫温度の上昇と共にモノスルフィド結合が増加（耐熱性向 上，耐疲労性低下）

加硫時間が長くなるとモノスルフィド結合が増加

2 ）低硫黄，高促進剂，高金属酸化物系 $\mathrm{EV}$ 加硫系を基本配合と した高温高速加硫系

スルフェンアミド系，チウラム系＋低硫黄＋高酸化亜鉛配 合

3 ) 高熱伝導度, 低発生ガス (加硫剤分解生成ガス) 配合とベン 卜押出作業

であり，Hybrid Crosslinkと呼ばれていることはよく知 られている。

EPDM の場合架橋速度の速いENB タイプを選択すると 架橋度の低下を抑えることが出来るとの指摘もある.

通常，ジエン系ゴムの加硫促進剤としてスルフェンアミ ドが代表的な高温高速加硫系である. BBSは加硫が速く, CBS, OBSもよく使われるが，二次加硫促進剂として DPG，TMTM，TMTD，DOTGを使用すると良い。酸化 亜鉛の増量は加硫速度を促進する. メルカプタン変性のク ロロプレンにはMBTS-ETU(エチレンチオウレア)系, 塩 素化ブチルにはチアジアゾール誘導体の加硫速度が速い. 
<smiles>CC1=CC(=O)N(Cc2cccc(CN3C(=O)C=C(C)C3=O)c2)C1=O</smiles>

BCIの分子㮱造

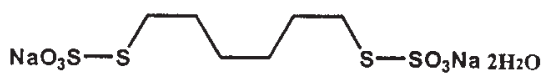

HTS の分子構造

図 15 高温高速加硫での加硫密度の低下対策用架橋片

耐熱性付与剂は， $6 \mathrm{QDI}(N-(1,3-$ ジメチルブチル)- $N$ ’-フ エニル-p-キノリンジイミン)が優れており, 硫黄加硫時に ゴム分子と結合して耐熱性，耐抽出性を向上させる ${ }^{13)}$. CSM用としては特にNiBDCの効果が高い。

過酸化物架橋系は，高温高速加硫系として特にEPDM に使われる。半減期による架橋速度の設定が容易であり， スコーチ安定性，耐熱性が優れている，架橋剤分解ガス量 がやや多く発泡し易い。適正添加量を越えると耐熱劣化に 影響することが指摘されている，過酸化物架橋の特徵と効 果的な使用方法について表 5 に示す.

\section{4.あと がき}

今回は生産性向上を目指す高温高速加硫技術の中の連続 加硫技術，金型加硫技術と加硫系についてまとめてみた. その他記述の足りない点があると思うが紙面の都合で省略 させて頂いた。お許し頂きたい.

\section{References}

1 ) Nishizawa, H.: Dai 136-kai Gomu Gijutsu Symposium Text, Nippon Gomu Kyokai (2007)

2 ) Troester Co. Ltd.: CCV,VCV Technical Report (2000)

3 ) "Kakyo Setsubi Handbook", Taiseisha Ed., Taiseisha, Tokyo (1983)

4 ) NEXTROM Co. Ltd.: CCV, VCV Technical Report (2000)

5 ) Nishizawa, H.: Seikeikakou, 13, No4, P-217 (2001)

6 ) Mitsuba Mfg. Co. Ltd.: Shear Head Extruder Report (1999)

7 ) Matsuda Seisakusho Co. Ltd.: Injection Molding Equipment Catalog (2000)

8 ) Kimura, Y.: Nippon Gomu Kyokai Kanagata Kenkyu Bunkakai Siryo, Nippon Gomu Kyokai (2005)

9 ) Seiki Co. Ltd.: Technical Report (2002)

10) Mouri, H.: Dai 40-kai Nippon Gomu Kyoukai Kaki Kouza Text, 73 (2003)

11) Datta, H. N.: Kautsch. Gummi Kunstst., 171, 1073 (1998)

12) White, J.R.; De, S. K. Eds.: "Rubber Technologist's Handbook", Smithers Rapra Technology, London (2001)

13) Dick, J. S.: "Rubber Compounding", Hanser, Munich (2004)

\section{日本語表記参考文献}

1）西沢仁：第136回ゴム技術シンポジウムテキスト，日本ゴム協 会 $(2007)$

2 ) Troester 社：CCV，VCV 技術資料 (2000)

3 ）架橋設備ハンドブック，大成社編大成社，東京 (1983)

4) NEXTROM社：CCV，VCV 技術資料 (2000)

5 ) 西沢仁 : 成形加工, 13，217 (2001)

6 ）三葉製作所：シャーヘッド押出機技術資料 (1999)

7 ) 松田製作所：射出成形機技術カタログ (2000)

8 ）木村洋治：日本ゴム協会金型研究分科会資料，日本ゴム協会 (2006)

9 ）世紀製作所技術資料 (2002)

10）毛利浩：第40回日本ゴム協会夏期講座テキスト，73 (2003)

表 5 代表的な高温高速架橋用過酸化物の特徵と使用方法

\begin{tabular}{|c|c|c|c|}
\hline $\begin{array}{l}\text { 化合物名 } \\
\text { 分子量 }\end{array}$ & $\begin{array}{l}\text { 1,1-Bis (tert-butylperoxy) -3,3,5-trimethy } \\
\text { lcyclohexane } \\
\qquad 302\end{array}$ & $\begin{array}{c}\text { Dicumyl peroxide } \\
270 \\
\end{array}$ & $\begin{array}{l}\text { 2,5-dimethyl -2,5-bis (tert- } \\
\text { butylperoxy) hexane } \\
290\end{array}$ \\
\hline 架橋形態 & $-\mathrm{C}-\mathrm{C}-$ & $-\mathrm{C}-\mathrm{C}-$ & $-\mathrm{C}-\mathrm{C}-$ \\
\hline 架橋時の分解生成物 & 未確認 & $\begin{array}{l}\text { アセトフェノン, メタ } \\
\text { ン,クミルアルコール, } \\
\text { 水 }\end{array}$ & 未確認 \\
\hline 1 分間半減期温度 $/{ }^{\circ} \mathrm{C}$ & 148 & 171 & 179 \\
\hline 10 時間半減期温度 $/{ }^{\circ} \mathrm{C}$ & 90 & 117 & 118 \\
\hline 架橋温度, 時間 & $148{ }^{\circ} \mathrm{C}, \quad 5 \sim 10$ 分 & $171{ }^{\circ} \mathrm{C}, \quad 5 \sim 10$ 分 & $179{ }^{\circ} \mathrm{C}, \quad 5 \sim 10$ 分 \\
\hline ロール加工温度上限 & $90{ }^{\circ} \mathrm{C}$ & $117^{\circ} \mathrm{C}$ & $118^{\circ} \mathrm{C}$ \\
\hline 適正添加量/phr & 3.02 & $\begin{array}{l}\quad 2.8 \sim 3.2 \\
\text { 不足 }-\quad \text { 加硫不足 } \\
\text { 過剩 }-\quad \text { 耐熱劣化低下 }\end{array}$ & 1.45 \\
\hline 架橋物の臭気 & 殆どなし & 大 & 殆どなし \\
\hline 共架橋剤 & $\begin{array}{l}\text { アクリル酸亜鉛 } \\
\text { TAIC, TAC, } \\
\text { TMPT, QO等 }\end{array}$ & 同一 & 同一 \\
\hline 特徵 & $\begin{array}{l}\text { 耐熱性 } \\
\text { 化審法の第一種監視化学物質であり, 現 } \\
\text { 在国内での生産・輸入はゼロ }\end{array}$ & $\begin{array}{l}\text { 耐熱性, スコーチ安定 } \\
\text { 性, 金型成形時の発泡 } \\
\text { に注意 }\end{array}$ & 耐熱性，スコーチ安定性 \\
\hline
\end{tabular}

